INTRODUCTION: HISTORICAL PERSPECTIVE

At the moment, the New Zealand system of industrial relations is in transition. For almost eight decades, it was dominated by the Industrial Conciliation and Arbitration Act (1894). With the passage of the Industrial Relations Act (1973) at the behest of the social partners(1), a significant shift in underlying philosophy has occurred. The full ramifications of this change have yet to develop. They have certainly not yet been grasped by the wider community and even by some within the ranks of the social partners.

The development of the old system of conciliation and arbitration has been amply described elsewhere(2). Here it will suffice to say that the Act of 1894 largely predated the appearance of modern industrial relations in New Zealand. It provided a rough measure of justice in employment matters by establishing minimum conditions of employment across the mainly small scale industries (and occupations) serving a predominantly pastoral community. It sought to create generalised procedures eliminating the need for industrial stoppages which seemed particularly likely to occur in areas where the community as a whole (and farmers in particular) had a vital interest. With the wisdom of hindsight, one can speculate whether this system was as successful as appeared on the surface. It may well have masked rather than solved problems (3). In an egalitarian pastoral society, it was nonetheless acceptable for a long period. In a more complex and diversified economy committed to full employment, it has be-

come less and less relevant to the realities of the world of work. It has fragmented the trade union movement and long delayed the development of solidarity within the ranks of the social partners.

The generalised approach to award making embodied in the Act of 1894 requires a fairly simple and stable environment to be successful. When conditions encourage industrial non-conformity and the introduction of diversified technologies, minimum conditions for the whole of an industry or occupation cease to match the realities of particular work-places (4). Furthermore, with full employment and consequent competition for labour, ruling rates of pay pull away sharply from those negotiated in awards. As all these conditions became more and more prevalent during and particularly after World War II, direct bargaining (or collective bargaining outside the statutory system) emerged. These facts and the limited range of industrial matters subject to negotiation(5) gradually under-

* Professor Young is Director of the Industrial Relations Centre, Victoria University of Wellington,, New Zealand. His article is based on a paper he presented to the ILO/NORAD Industrial Relations Symposium for Asian Countries held in Manila in 1975.

(1) Most of the essential features of the new legislation were jointly submitted to government by the N.Z. Employers' Federation and the N.Z. Federation of Labour in 1972 who are the social partners referred to.

(2) N. S. Woods, Industrial Conciliation and Arbitration in New Zealand, Wellington, Government Printer, 1963.

(3) Even as industrial conciliation and arbitration were introduced, the maritime trades, other forms of transportation, the meat freezing industry and probably the coal mines were beginning to experience modern industrial relations problems as a result of their environment and scale of operations. Periodic outbursts like the Waterfront Disputes of 1913 and 1951 and further legislative intervention in the form of the Labour Disputes Investigation Act (1913) and the Waterfront Industry Act (1953) point to significant limitations in a generalised and legislative approach to industrial relations.

(4) For a detailed discussion of the problem vide: N. S. Woods, The Industrial Relations Act 1973, Occasional Paper No. 11, Industrial Relations Centre, Victoria University of Wellington, 1974, pp. 1-7.

(5) Typically an award was in writing and spelled out: the type of workers to be covered by its provisions, wage rates, hours of work, shifts and overtime, statutory holidays and vacations, conditions of work and payment of wages, sickness, accidents and first aid provisions, meal hours and meal money, dining and changing rooms, rest periods and smoko, termination of employment, union secretary's right of entry, notification of names of workers to union secretary, union preference clause, disputes committee, provision of a copy of the award to workers, application and scope of the award. There was a very evident emphasis on matters of substance rather than matters of procedure. 
mined the credibility of the system. It is surely significant that the old legislation denied registered unions(6) the right to strike and yet stoppages still occurred. Frequent causes were allegations of unfair dismissal and issues of safety. These were not matters which could be dealt with effectively under the then existing practices and procedures. Indeed in 1967, the Minister of Labour was constrained to argue that "the country's legislation and institutions were largely "inapplicable to the circumstances of 1967, let alone 1977'(7).

By the early 1970 s it was evident that in-plant and work-site bargaining had become well established in New Zealand. In the private sector this was anything but systematised. A host of different forms of agreement had been superimposed upon the formal system of award making. The problem of "instant" relativity was bedevilling the wage structure in inflationary conditions ${ }^{(8)}$. The realities of institutional employment were clearly at odds with the ployment were clearly at odds with the ideology of the lindustil conciliation and Arbitration Act although they had long been accommodated within the state system of negotiating terms and conditions of employment. A few large enterprises and organisations had become pace-setters in industrial relations matters. While they amounted to no more than $2 \%$ of the total, they generated at least $41 \%$ of surveyed employment(9)

\section{THE INDUSTRIAL RELATIONS} ACT, 1973

The pressures created by this changing climate of industrial relations undoubtedly led to the passage of the Industrial Relations Act 1973(10). While this statute continues the long established tradition of conciliation and arbitration, its new institu-

(6) To take advantage of the procedures of the Industrial Conciliation and Arbitration Act, a trade union ha to register as an industrial union of workers. It then became subject to awards of the Arbitration Coun
and the supervision of the Registrar of Industrial Unions in matters of internal administration. Offsettin advantages lay in the exclusive right io negotiate on behalf of the workers involved and the power cite the employer (or industrial union of employers) to enter into conciliation or appear before the Arb.
tration Court. With the immature state of industrial relations in the 1890 s and the first part of the 20 th century, most trade unions appear to have seen positive advantages in registration although it legally sive right to negotiate. For weak and fragmented unions this represented a serious threat. Where solidarit

(7) T. P. Shand, "The Role of Government in New Zealand in Wage Bargaining and Settlement of Disputes" (8) For general background, vide New Zealand Monetary and Economic Council, Inflation and the Labou
Market, Report No. 22, December 1971 . (9) F. J. L. Young, "The Labour Market in New Zealand," in John M. Howells, N. S. Woods and F.
L. Young (eds), Labour and Industrial Relations in New Zealand, Pitman Pacific Books, 1974. (10) For two views of this statute vide: N. S. Woods, "The Industrial Relation Act 1973,", op.cit., and Jo
Seidman, "New Zealand's Industrial Relations Act 1973," International Labour Review, Vol. 110, No.
1974. and their officers; preferential employment; and items which any statute states to be industrial matters. Again, it will be noted that apart from the three matters just spelled out, the question of what constitutes a right is left deliberately vague.

Linking the latter interpretations with the disputes and personal grievance procedures, it is evident that the scope of collective bargaining has been widened. A peace obligation has been introduced where the parties are disputing the meaning or application of rights which they have written into a collective agreement or award. Here the aim of the legislators appears to have been twofold: to update industrial legislation in terms of emerging industrial relations practice (institutional employment) and to underline the public conflict. The latter objective is meant to be achieved by providing machinery which makes recourse to direct action unnecessary in settling disputes of rights.

The widening of the scope of collective bargaining comes out clearly in the matter of personal grievances. Not only is a claim of unjustifiable dismissal to be considered a personal grievance, so too is any claim advantage of the individual employee. The concept of "iust cause" has been introduced into the New Zealand system of industrial relations. In other words, whilst employers remain free to initiate action affecting individual employees, they are now under an obligation to exercise due care and not to discriminate in their action. Practically this would seem to involve a host of matters which have not previously been generally negotiable in the private sector: promotions, demotions, transfers, lay offs and disciplinary action. If allegations of discriminatory treatment can now be challenged and reviewed by way of the trade unions has been changed just as much as that of the employer. The enhanceinterest in avoiding unnecessary industrial of discriminatory treatment(11) to the dispersonal grievance procedure, the role of

ment of the trade union's representative unction (here, the widening of the scope of workplace bargaining) has been balanced by a peace obligation in all disputes of rights. "Industrial massage" is clearly not permitted in such conflicts as an alternative method is provided for the peaceful resolution of disputes of rights.

The essence of the new legislation is consequently to encourage the parties to make their own rules as far as possible. Once these rules have been established, matters of procedure and matters of substance become rights. Even then the emphasis remains on encouraging settlement of disputes of rights by direct negotiation or in disputes and grievanoliation or in disputes and grievance connitees. The role of the Industrial Court seems to be essentially that of a backstop resolving issues of particular difficulty or more general interest. Demarcation disputes, however, provide a specific example of the Court replacing normal procedures which would not be adequate for the problems involved.

\section{TRANSITIONAL ASPECTS}

It is too early to assess the impact of the new legal framework upon those cov ered by its provisions. Some idea of possible developments may, however, be obtained by examination of "public sector" practice(12). Institutionalised industrial relations have long existed in public employment in Now Zealand, usually without the traitiacket of registration and strailfacket of registration and other administrative controls found in the private sector. In terms of Kenneth F. Walker's definition and categorisation of worker participation in management $(13)$, trade unions in state organisations in New Zealand have been highly successful in creating countervailing power through collective action. This has gone well beyond establishing fair wages and relativities. Influence over terms and conditions of employment and many areas of management decision making is extensive. Moreover, in some (11) The wording of the statute defines such treatment as action "not being an action of a kind applicabte
generally to workers of the same class employed by the employer."

12) In New Zealand the distinction between private and public sectors is fairly blurred because of the
nature and extent of state enterprise. For present purposes, the public sector should be taken to mean nature and extent of state enterprise. For present purposes, the public sector should be taken
activities in which the Combined State Service Organisations represent the workers involved.

(13) Kenneth F. Walker, "Worker Participation in Manageme
International Institute for Labour Studies, No. 12, 1975..
"Bulletin of 
areas both ascending and descending participat

accept the view that a democratically elected government must decide what policies it wants have implemented. Nonetheless, many of them would argue that "there is scope, and considerable scope, for public servants to have a say in how their work may be have" (15). With widely diffused and rising donels of education, such a desire is unlikely to public service likely to be what is already common employment. What is altor must almost practice in the public sectore employment inevitably spread

over the long run.

In fact, there is evidence of some stirring sector in the direction just mentioned. Before the passage of the Industrial Relations Act, the Department of Labour undertook a survey of worker participation in management in manufacturing industry. In July $1972,12.5 \%$ of 2,027 firm employing more than 20 persons reported some form of participation (i operatents). While the somerticipaDepartis employed by

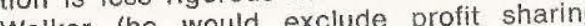
Walker (he would excluding) the results and employee sharem Nearly $60 \%$ are nonetheless notewortion the instances of participation involved joint consultation alone or in association with some other element. Autonomous work groups were present in $24 \%$ of the cases, while profit sharing and tradeable shares were found in $15 \%$ and $20 \%$ respectively. The incidence of participation clearly increased as the size of the labour force involved increased; however, while autoninvol work-groups became less frequent the larger the labour force, joint consultathe larger thefinitely associated with larger

14) For a general discussion see E. J. Keating, "Trade Unionism in State Organisations" and J. F. Robe op.ci. "Legislation and Industrial Relations in more specific details. The Post Office for example operates with a IossoUnvulsory system ascending from its branches to Head offlce. At the same the Government Superanciation has representation on the punangerial functions is evident in other departments. unions and the Railways Department have a system in investigation and recommendations on
participation is also evident on the railways with joint matters as grading of shunting yards, dirty work and the amalgamation of trades or unpublished papers (15) The late D. P. Long, Generat (16) Department
May 1975.

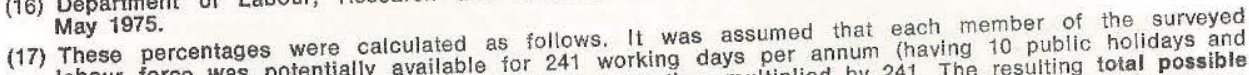
These percentages were calculated as follows.
labour force was potentially available for 241 working days per annum (having 10 public holidays and
two weeks vacation). The surveyed labour force was then multiplied by 241 . The resulting total possible
mandays of work and actual mandays lost in stoppages were then used in calculating the percentages. (18) For a detailed and careful examination of this problem vide John M. Howells, "In only three mediators have been appointed, but reports indicate that they have had a considerable measure of success in resolving conflicts. It is perhaps significant that mediator, unlike a conciliation commissioner, has very limited powers. Even it he is invited to hand down a decision, acceptance of his ruling depends upon the consent of the parties (19)

In the writer's opinion, New Zealand now stands at a watershed in industrial relations matters. On the one side lies the uncertainty associated with all innovation and experimentation on the other, the prospect is one of retrogression associated with ideas and activities which are becoming more and more outmoded in a modern rganised society. The issues involved are urther complicated by the fact that around $35 \%$ of the country's overseas earnings come from pastoral products. There is still consideral dichotomy interest and understanding between the urbanised industrialised community and the farming sector. Yet many of the imported raw materials essential to urban employment depend upon income from pastoral exports. Apart from conflict over the joint product, a similar dichotomy exists within the urbanised industrial community. It has a number is dimensions associated with age, educaof dimensions associated with age, educa tion, experience and environment. In sum,
all these pressures point to a society and industrial relations system in transition. FUTURE DEVELOPMENTS

As far as industrial relations is concerned, there are clear pointers to the direction of future developments. Tripartitism is well established at the national level in various organisations involved in economic and social planning. More specifically, the ed in a number of institutions and agencies in addition to those set up under the in addition to those set up under the theme throughout many of these activities $s$ been the upgrading of industrial relaof Report of the Commission of Inquiry into the Meat Industry (1974) makes useful reading(21). Many of its comments and recommendations are of more general application

There is now widespread acceptance of the value of education and training in improving productivity, in eliminating waste of human effort and materials. Attempts appear to be under way to work out the linkage between national active employment policies and workplace industrial relations(22) Issues are being accepted which were ignored or denied a decade ago. Supervisors are being made aware that their skills must include the effective exercise of authority. Management is grasping the importance of well designed schemes of induction, training and development in creating status and a sense of commitment to particular work. In this respect, formalisation of promotion and seniority procedures is emerging(23). An expansion of collective bargaining is undoubtedly way, particularly in the workplace.

This expansion of collective bargaining certainly mirrors the growth of institutional employment, a fact which some commentators and members of the public find hard to accept. The social partners need time to determine priorities and substance, and ime to familiarise those involved with the purposes and procedures of collective
bargaining. Until 1973, the legislation was a positive deterrent to the creation of modern industrial relations practice. expect the system to be reconstructed in two years after 80 years of rigid control is really too much. Apart from anything else, there are simply not enough trained personnel (especially foremen and job deleinvolved.

(19) N. S. Woods, The Industrial Relations Act 1973, op.cit., p. 17

0) The President of the Federation of Labour is Chairman of the New Zealand Shipping Corporation. A
member of the National Executive of the Federation of Labour is a member of the Board of the Reserve member of the National Executive of the Federation of Labour is a member of the Board of the Reserve
Bank. Employers, trade unionists and public servants work together on the various training boards
set up under the Vocational Training Council, on the Trade Union Training Board and organisations
like the National Advisory Council on the Employment of Women.

1) Report of the Commission of Inquiry into the Meat Industry, Wellington, Government Printer, 1974, 22) The Industrial Relations Council has held discussions on redund
examining the questions of absenteeism and accident prevention. The extent to which disputes committees and personal grievance procedures can be used to establish
the details of rights within the workplace has yet to be grasped. To date the majority of disputes of riahts appear to have revolved around dismissals, the application of special payments and matters
like severance pay. Promotions and seniority seem to have received relatively little attention as yet. 